MIRAN MARELJA

Sveučilište u Zagrebu, Pravni fakultet miran.marelja@pravo.hr

\title{
PITANJE EUROPSKE KOLEKTIVNE SIGURNOSTI U RAZDOBLJU OD VERSAJSKE MIROVNE KONFERENCIJE DO UGOVORA IZ LOCARNA (1919.-1925.)
}

U radu je prikazano stvaranje sustava europske kolektivne sigurnosti nakon završetka Prvog svjetskog rata. Posebna pozornost posvećena je pravnim, ali i političkim i ekonomskim čimbenicima koji su utjecali na stabilizaciju europskog poretka tijekom 1920-ih godina.

\section{UVOD}

Strahote Prvog svjetskog rata donose konačan slom međunarodnog poretka uspostavljenog na Bečkom kongresu 1815. godine, tzv. Koncerta europskih sila koji je Europi osigurao stoljeće relativno stabilnog mira. ${ }^{1}$ Promjene koje su zahvatile Europu drastično će preoblikovati političku, ekonomsku, socijalnu i ideološku sliku Europe. Propast višestoljetnih autokratskih mnogonacionalnih carstava i afirmacija načela na samoodređenje naroda otvaraju put osnivanju niza novih

1 Mark MAZOWER, Governing the World. The History of an Idea, Penguin Books, London, 2012, 3-12. Najznačajnije iznimke su Krimski rat 1853.-1856. i Francusko-pruski rat 1870.-1871. godine. 
nacionalnih država u Istočnoj i Srednjoj Europi. Uz to, ekonomsko osiromašenje Europe koja je do tada dominirala svjetskom ekonomijom i pomicanje središta ekonomske moći prema SAD-u, te uspon liberalne demokracije i pojava novih autoritarnih političkih poretka, komunizma i fašizma, koji će ponuditi radikalne utopijske vizije suvremenog društva odredit će povijest Europe u 20. stoljeću. Dok novi svjetski poredak niče na ruševinama četiri carstva, na međunarodne odnose snažno djeluje i neočekivani povratak SAD-a izolacionizmu, čije je ekonomske, političke i vojne kapacitete potvrdio upravo minuli rat, kao i međunarodna izolacija omraženog Sovjetskog saveza protiv kojeg ratne pobjednice vojno interveniraju po završetku rata. ${ }^{2}$

U ovom radu se analizira stvaranje i stabilizacija sustava europske kolektivne sigurnosti nakon završetka „Velikog rata“ do sredine 1920-ih godina, odnosno sklapanja ugovora iz Locarna kao prijelomne točke kojom započinje kratkotrajno razdoblje popuštanja napetosti između europskih sila. Rad započinje s izgradnjom poslijeratnog svijeta na Pariškoj mirovnoj konferenciji, čija će rješenja obilježiti život Europe između dva rata. Mirovnim ugovorima se osigurava podčinjeni položaj ratnih gubitnica koje i same prolaze tektonske političke promjene. Podvrgavanje njihovog ekonomskog života interesima pobjednica dijelom je motivirano sprječavanjem kakvog budućeg rata, a u istu svrhu se u okviru Lige naroda uspostavlja sigurnosni mehanizam temeljen na kolektivnoj sigurnosti. Slijedi kraći prikaz sustava kolektivne sigurnosti Lige naroda, koji je trebao poslužiti kao instrument očuvanja svjetskog mira, pri čemu su mirovni ugovori Pariške konferencije usmjereni na umanjenje vojnih i ekonomskih, a time i političkih kapaciteta poraženih država, poglavito Njemačke, da bi se potom sigurnosnim mehanizmima Lige naroda povjerilo očuvanje statusa quo. Sredinom 20-ih godina postaje sve jasnije kako je europska stabilnost u velikoj mjeri talac bilateralnog odnosa Francuske i Njemačke te da sigurnosni mehanizam Lige nije adekvatan za rješenje latentnog sukoba ove dvije države. Upravo će francuski zaokret u vanjskoj politici, kojeg simbolizira uspon Aristida Brianda, jednog od najistaknutiji europskih političara tog doba koji je od 1925. do 1932. godine naizmjenice bio francuski premijer i ministar vanjskih poslova, otvoriti mogućnost deeskalacije sukoba, što će u konačnici potvrditi ugovori iz Locarna 1925. godine. Locarnski sporazumi pokazat će korisnost regionalnih sustava kolektivne sigurnosti kao dopune Ligi naroda. Međutim, njihov domet je bio kratkog vijeka te će neuspjeh Lige naroda da odgovori na krizu međuratnog europskog poretka koji je i dalje

2 Vidi John B. QUIGLEY, Soviet Legal Innovation and the Law of the Western World, Cambridge University press, Cambridge, 2007., 68-72. 
počivao na sustavu ravnoteže snaga i izbijanje Drugog svjetskog rata pokazati potrebu prihvaćanja novog europskog poretka nakon 1945. godine koji će počivati na politici europske integracije.

\section{PARIŠKA MIROVNA KONFERENCIJA}

Bezuvjetnom predajom Austro-Ugarske u listopadu 1918. godine i potpisivanjem primirja između Osmanskog Carstva i sila Antante, Njemačka ostaje bez potpore ratnih saveznica. Svijest o predstojećem porazu, glad i iscrpljenost ratom ubrzo će dovesti do abdikacije njemačkog cara Wilhelma II. i stvaranja Weimarske Republike. ${ }^{3}$ Potpisivanjem primirja u Compiègneu 11. studenog 1918. godine Njemačka konačno polaže oružje, pri čemu odredbe ovog ugovora u osnovnim crtama uređuju najbitnija pitanja poput obustave neprijateljstava, povlačenja njemačke vojske, oslobađanja (savezničkih) ratnih zarobljenika, njemačkog prihvaćanja obveze ratnih reparacija i dr. Odredbe ugovora o primirju bile su tek prijelazno rješenje do sazivanja mirovne konferencije koja počinje s radom u Parizu 18. siječnja 1919. godine, a na kojoj sudjeluju predstavnici 27 zemalja. Međutim, aktivno sudjeluju samo predstavnici zemalja pobjednica, jer su za razliku od kongresa iz prošlosti predstavnici poraženih zemalja isključeni iz rada konferencije te će im biti prezentirane konačne verzije mirovnih ugovora s njihovim zemljama. ${ }^{4}$ Treba imati na umu da su se odluke o bitnim pitanjima na Pariškoj mirovnoj konferenciji donosile kompromisom šefova delegacija i ministara vanjskih poslova okupljenih u Vijeće desetorice, koje će se uslijed političkih potreba velikih sila ubrzo preobraziti u Vijeće petorice, kojeg čine delegacije Francuske, Velike Britanije, Japana, Italije i Sjedinjenih Američkih Država. ${ }^{5}$ Predstavnici drugih država

3 Tako Norman A. GRAEBNER, Edward M. BENNETT, M., The Versailles Treaty and Its Legacy: The Failure of the Wilsonian Vision, Cambridge, Cambridge University Press, 2011., 35. Abdikacija je bila preduvjet potpisivanja primirja.

4 Svi mirovni ugovori su izrađeni bez sudjelovanja poraženih država; nakon izrade ugovora isti je dostavljen na potpis poraženoj državi koja ne samo da nije sudjelovala u pregovorima i definiranju pojedinih odredbi odnosno izražavanja rezerve na pojedinu odredbu, nego su na ugovorne odredbe mogle tek pristati ili ih odbiti u cijelosti. Kako bi se ova rigidnost donekle ublažila, predviđeno je da se poražena država može u konačnici očitovati pismenim opaskama na predočeni ugovor. Kad njemačka delegacija odbije potpisati mirovni ugovor, Velika Britanija započinje blokadu njemačkih luka. Isto, 40, 57-60.

5 Vidi Livia KARDUM, „Diplomatska borba za Korušku na Pariškoj mirovnoj konferenciji 1919. godine“, Politička misao, sv. 38, br. 1, 2001., 126. Delegacije u pravilu predvode nositelji izvršne vlasti pojedinih zemalja, pri čemu su predstavnici pet velikih sila dolazili do rješenja kakvog pitanja nakon dugotrajne međusobne rasprave. Ipak, ukoliko se nije raspravljalo o pitanju od interesa za Japan, predstavnici Japanskog Carstva su također bili isključeni čime bi se prvotno Vijeće desetorice transformiralo u Vijeće četvorice. U manjoj mjeri, Italija se također znala naći u podređenom položaju u odnosu na „veliku trojku“. 
IVAN OBADIĆ, MIRAN MARELJA: Pitanje europske kolektivne sigurnosti u razdoblju od ...

članica pobjedničkog saveza sudjeluju u radu Plenuma mirovne konferencije (bez stvarnih ovlasti), dok se Vijeću priključuju po potrebi i isključivo na poziv Vijeća, kada se raspravlja o nekom za njih važnom pitanju ili kako bi dostavili zahtjeve svojih zemalja u pogledu određenog pitanja. ${ }^{6}$ Usvojena rješenja su posljedično nametnuta ne samo ratnim gubitnicama, nego u određenoj mjeri i ostalim zemljama, čak i ukoliko su bile članice pobjedničke koalicije. ${ }^{7}$

Versajskim debatama dominirala su pitanja o zahtjevima za stvaranje nacionalnih država i nove političke karte Europe nakon sloma Njemačkog, Ruskog, Habsburškog i Otomanskog carstva, izolacije novog revolucionarnog boljševičkog režima u Rusiji koji je prijetio svjetskom revolucijom te redefiniranja odnosa među pobjedničkim silama. ${ }^{8}$ No, najvažnije pitanje predstavljalo je rješavanje njemačkog pitanja i slabljenje njezine moći kako bi se osigurao stabilan mir koji bi učinio ponovni rat nemogućim. Mirovna konferencija trebala je kroz mirovne ugovore i uspostavu Lige naroda osigurati svjetski mir no već na početku rada Pariške konferencije postaju jasne razlike među državama pobjedničke koalicije u njihovim pogledima na poslijeratni europski poredak. Razmirice ne čude, jer su se SAD i Velika Britanija vođene vlastitim interesima protivile francuskim zahtjevima da Njemačku treba strogo kazniti zbog agresije te držati pod striktnom kontrolom kako ne bi ponovno izazvala rat, potvrđujući tako Francuskoj da ne može računati na anglo-američku potporu u ostvarivanju svoje rigidne politike prema Njemačkoj. Osnovna zamisao ugovora počiva na dužnosti reparacije štete te ekonomskom podvrgavanju poraženih država dok bi im se unutrašnji politički život ostavio u vlastitim rukama. ${ }^{9}$ Pri tome, Weimarska Njemačka ne samo što je razoružana i znatno teritorijalno umanjena u odnosu na Drugo Carstvo, nego

6 Isto. Rad Konferencije znatno otežava dolazak cijelog niza delegacija različitih naroda, koje su imale različite, a često i suprotstavljene zahtjeve.

7 Po uzoru na Versajski mirovni ugovor rađeni su kasniji ugovori s drugim poraženim silama: s Austrijom u Saint-Germain-en-Layeu (potpisan 10. rujna 1919. godine, stupio je na snagu 16. srpnja 1920. godine), s Bugarskom u Neuilly-sur-Seineu (potpisan 27. studenog 1919. godine, stupio je na snagu 9. kolovoza 1920. godine), s Mađarskom u Trianonu (potpisan 4. lipnja 1920. godine, stupio je na snagu 16. srpnja 1920. godine) i s Turskom u Sèvresu (potpisan 10. kolovoza 1920. godine od strane Turske carske vlade, no Carstvo ubrzo pada te posljedično Turska nikad nije ratificirala mirovni ugovor koji stoga nije stupio na snagu).

8 Eric HOBSBAWM, Doba Extrema, Dereta, Beograd, 2002., 30-31. Pobjedničke sile su težile zadovoljiti vlastite interese, pa su primjerice francuski politički i vojni krugovi polazili prvenstveno od rješavanja njemačkog pitanja s obzirom da je od ratnog razaranja pošteđena Njemačka svojim ekonomskim i vojnim potencijalom mogla narušiti francusku dominaciju na kontinentu.

9 Ekonomska podređenost ostavlja posljedice i na političkom planu. Kritiku ovakvog pristupa pobjednica kao i razlikama u njihovom pristupu nakon Drugog svjetskog rata vidi u Patricia CLAVIN, „Reparations in the Long Run“, Diplomacy \& Statecraft, sv. 16, br. 3, 2005., 520. i dalje. 
je i prokazana kao inicijator, a time i krivac za svjetski rat, što posljedično prati zahtjev za isplatu ratne štete. ${ }^{10}$

Primjetno je kako oštrina ugovornih odredbi znatno nadilazi ionako stroge odredbe potpisanog primirja s Njemačkom, a pri izradi mirovnog ugovora nisu se ispunila niti njemačka očekivanja o uvažavanju sadržaja 14 točaka predsjednika Wilsona. ${ }^{11}$ Američki predsjednik svoju viziju novog svijeta prvotno predstavlja u govoru Kongresu od 8. siječnja 1918. godine kao Četrnaest točaka, a potom razrađuje predsjedničkom izjavom, pri čemu fokus stavlja na globalno ograničenje naoružanja, mir bez pobjednika te posebno pravo naroda na samoodređenje, ograničeno doduše na političku sferu, a ne i na ekonomsku. ${ }^{12}$ Naime, unatoč Wilsonovom postulatu „ukidanja svih ekonomskih prepreka“, upravo američki delegati odbijaju francusku inicijativu o proširenju prijedloga američkog predsjednika i na odnose među državama kroz povjeravanje određenih nadležnosti Lige naroda glede ekonomskih odnosa između država. ${ }^{13}$ Za ovaj rad, posebno je značajna Wilsonova ideja o očuvanju mira kroz sustav kolektivne sigurnosti umjesto dotadašnjeg sustava koji je počivao na ravnoteži snaga.

\section{IZGRADNJA SUSTAVA KOLEKTIVNE SIGURNOSTI NA MIROVNOJ KONFERENCIJI}

Tračke uobličenja mehanizma koji počiva na kolektivnoj sigurnosti u međunarodnim odnosima nalazimo već u starovjekovnim i srednjovjekovnim izvorima, a potom i u čl. 124. čuvenog Vestfalskog mira iz 1648. godine, kojim države-potpisnice pod određenim uvjetima jamče kolektivnu zaštitu od oružanog napada

10 Kraći prikaz teritorijalnih promjena na uštrb Njemačke daje Antony Evelyn ALCOCK, A History of the Protection of Regional Cultural Minorities in Europe, Palgrave Macmillan, 2000., 43.

11 Njemačka javnost je pravo naroda na samoodređenje promatrala u kontekstu težnje stanovništva Weimarske republike i Austrije, kao i Sudetske oblasti u nekadašnjoj Bohemiji gdje su većina bili Nijemci, na ujedinjenje u jedinstvenu nacionalnu državu o čemu će još biti riječi. Rolf STEININGER, Austria, Germany, and the Cold War: From the Anschluss to the State Treaty 1938-1955, Berghahn Books, New York, Oxford, 2012., 1-4.

12 Vidi Wilson, W., Četrnaest točaka predsjednika Wilsona, tekst dostupan na web adresi: https://avaIon.law.yale.edu/20th_century/wilson14.asp, posjećeno 20. rujna 2019. Pojedine elemente Četrnaest točaka Wilson je spominjao i u ranijim istupima, da bi ih potom objedinio u svom čuvenom govoru pred Kongresom. Također, u kasnijim govorima Wilson dodatno širi i razrađuje pojedine točke, pa primjerice u govoru od 11. veljače 1918. godine izrijekom navodi da bi buduća mirovna konferencija u svom radu nužno morala uvažiti načelo samoopredjeljenja.

13 Glede predložene slobode trgovine treba imati u vidu da ovakva odredba pogoduje prvenstveno zemljama čije su ekonomije razvijene i pošteđene ratnih razaranja. Vidi Walter A. MCDOUGALL, „Political Economy versus National Sovereignty: French Structures for German Economic Integration after Versailles", The Journal of Modern History, vol. 51, br. 1., 1979., 4.-23. 
IVAN OBADIĆ, MIRAN MARELJA: Pitanje europske kolektivne sigurnosti u razdoblju od ...

na drugu potpisnicu. ${ }^{14} \mathrm{U}$ svijetu tzv. Koncerta europskih sila potvrđenog Bečkim kongresom 1815. godine, koji u svojoj suštini počiva na ravnoteži snaga, kolektivna sigurnost se potvrđuje kao utopija europske inteligencije. Ne treba stoga čuditi što njezino uobličenje i razradu pronalazimo ponajprije u Kantovom odbacivanju doktrine pravednog rata radi uspostave svjetskog mira. Uz odbacivanje stajaćih vojski Kant predviđa uspostavu savezne svjetske vlade u vidu „Društva naroda“, usmjerene na postizanje trajnog mira te stoga nadređene državama, ali samo u pitanjima vezanima za očuvanje svjetskog mira i slobode država. ${ }^{15} \mathrm{Na}$ ovom će tragu 125 godina kasnije predsjednik Wilson zahtjevati jamstva „političke neovisnosti i teritorijalne cjelovitosti podjednako za velike i male države“, pri čemu ishodište takvih jamstava zahtjeva uspostavu naddržavne strukture u vidu zajednice država. ${ }^{16}$ Unatoč Wilsonovoj tvrdnji kako je njegova misao vodilja odbacivanje "starog sustava saveza zvanog ravnoteža snaga", sustav kolektivne sigurnosti buduće Lige naroda se na Pariškoj mirovnoj konferenciji instrumentalizira sukladno interesima pobjednica, čineći ga svojevrsnom institucionalnom nadgradnjom ranijeg Europskog koncerta. ${ }^{17}$

Nimalo idealistički, sigurnosnim mehanizmom u okvirima Lige naroda velike sile teže očuvati status quo uspostavljen Pariškom konferencijom, čijim se rješenjima ratne gubitnice vojno i ekonomsko-politički podvrgavaju, poglavito Weimarska Njemačka kao jedina države koja je i dalje imala značajan potencijal za sudjelovanje u eventualnom budućem oružanom sukobu. ${ }^{18}$ Mirovnim ugovorima se stoga u svrhu očuvanja mira silama pobjednicama povjeravaju određena jamstva i posljedična prava, poput odredbe o osiguranju od iznenadnog napada koje treći dio Versajskog mirovnog ugovora pruža prije svega Francuskoj. ${ }^{19}$ Sličan

14 Pregled povijesnih i pravno-povijesnih izvora vidi u Gordan STRUIĆ, „Kolektivna sigurnost i njezini mehanizmi u paktu Lige naroda", Pravni vjesnik, sv. 33, br. 3-4., 2017., 201-202. Vidi i Davorin LAPAŠ, Sankcija u međunarodnom pravu, Pravni fakultet Sveučilišta u Zagrebu, Zagreb, 2004., 193-199.

15 Vidi Immanuel KANT, Toward Perpetual Peace and Other Writings on Politics, Peace, and History, Yale University Press New Haven/ London, 2006., 67-110, posebno stranice 69, 70-71, 78-81, 85-92. Promišljanja o kolektivnoj sigurnosti moguće je pronaći i kod ranijih autora poput Sullyja, Crucéa, Penna, de Saint-Pierrea i dr. Kraći pregled vidi u Alan SHARP, Collective Security, 2013., izvor dostupan na mrežnoj stranici: http://ieg-ego.eu/en/threads/alliances-and-wars/alliances-and-treaties/ alan-sharp-collective-security, posjećeno 15. studenog 2019. godine.

16 Wilson, n. dj.

17 Sharp, n. dj. Vidi i Struić, n. dj., 198-200.

18 Vidi i Allen W. Dulles, „Collective security“, American Society of International Law Proceedings, sv. 33, 1939., 119-120.

19 U ovom kontekstu treba promatrati i odredbe o zaštiti Belgije i Luksemburga od njemačke agresije (op.a.). 
ratio imaju odredbe o ograničenju vojne moći poraženih država kakve sadrže svi mirovni ugovori, čime se uvodi i nadzor proizvodnih industrijskih kapaciteta koji se mogu koristiti u vojne svrhe te se ujedno izravno ograničava brojnost vojnih snaga. lako je predsjednik Wilson zagovarao opće razoružanje, tj. razoružanje do najniže razine kojom se ne bi ugrožavala sigurnost pojedine države, ideja će se u konačnici primijeniti samo na ratne gubitnice. Njemačka vojska se tako ograničava na ukupno 100 tisuća vojnika čime mlada republika raspolaže dovoljnim snagama za unutrašnje potrebe, no takva vojna sila je nedostatna za sudjelovanje u kakvom ozbiljnijem međunarodnom sukobu. ${ }^{20}$

Ovo političko i sigurnosno pitanje je od prvorazredne važnosti, pa iako se za razliku od 19. stoljeća u vrijeme završetka Prvog svjetskog rata na sam rat gleda kao na izvanrednu situaciju odnosno neprirodno stanje u odnosima između država, pravo na rat i dalje pruža mogućnost ostvarenja političkih ciljeva te stoga rat per se nije protivan tadašnjem običajnom međunarodnom pravu. Ovu činjenicu odražava i Povelja Lige naroda, pa rat kao sredstvo rješavanja sporova između država samom Poveljom Lige nije zabranjen, tj. ovakvu zabranu (napadačkog) rata sadrži tek Povelja Ujedinjenih naroda iako se Pariški akt iz 1928. godine znatno približio navedenoj zabrani. ${ }^{21} \mathrm{Na}$ tragu rješenja Vestfalskog sporazuma iz 1648. i Chaumontskog sporazuma iz 1814. rat se stoga kao sredstvo tek suspendira u korist Poveljom predviđenog mehanizma rješavanja sporova u vidu arbitraže, sudskog postupka ili ispitivanja spora od strane Vijeća Lige naroda, kojem su se države članice bile dužne podvrći. ${ }^{22}$ Štoviše, ukoliko bi članica propustila udovoljiti svojoj dužnosti podvrgavanja spora predviđenom mehanizmu u sklopu Povelje (ili izvan nje, ukoliko su npr. izravni pregovori dostatni za otklanjanje napetosti), druge države članice imale su prema čl. 15 pravo obavijestiti Tajnika Lige o postojanju spora i na taj način inicirati predviđeni postupak arbitraže. Primjetno je nastojanje Lige da osnaži Stalni sud međunarodne pravde kao tijelo nadležno za otklanjanje međunarodnih sporova, kako bi potpomoglo napore Skupštine i

20 Njemačko zrakoplovstvo se odredbama ugovora ukida, a mornarica svodi tek na 6 bojnih brodova. Slično, ugovor iz Saint-Germaina u čl. 120. ograničava austrijsku vojsku na 30 tisuća vojnika, čl. 104. Trianonskog ugovora mađarsku vojsku na 35 tisuća, čl. 66. ugovora iz Neuillya ograničava bugarsku vojsku na 20 tisuća dok ugovor iz Sèvresa u čl. 155. ograničava tursku vojsku na 50 tisuća vojnika, čime su ove države faktično onemogućene u započinjanju kakvog budućeg oružanog sukoba.

21 Ugovor o odricanju od rata (kao sredstva državne politike), poznatiji kao Briand-Kellogov pakt, sklopljen je 27. kolovoza 1928. godine. Tekst Ugovora dostupan na mrežnoj stranici https://avalon.law. yale.edu/-20th_century/kbpact.asp, posjećeno 20. rujna 2019. godine.

22 Čl. 12. i 13. Povelje Lige naroda. U tu svrhu čl. 14. predviđa osnivanje Stalnog suda međunarodne pravde. Vidi i osvrt u G. STRUIĆ, n. dj., 202, 204. 
IVAN OBADIĆ, MIRAN MARELJA: Pitanje europske kolektivne sigurnosti u razdoblju od ...

Vijeća Lige, u čiju je nadležnost prema čl. 3 i 4 Povelje potpadalo i svako pitanje koje ugrožava svjetski mir. ${ }^{23}$

Kako bi se osnažili kapaciteti Lige u očuvanju svjetskog mira, rat kao i sama prijetnja ratom su prema članku 11. Povelje pitanja od interesa Lige naroda, čime se željelo onemogućiti podvođenje rata i prijetnje ratom pod kakvo „unutrašnje“ pitanje države odnosno država uključenih u ratni sukob ili onih koje se prijetnjom približavaju sukobu. Stoga, ne samo da se prema čl. 10 članice obvezuju poštivati političku neovisnost i teritorijalnu cjelovitost drugih članica, nego svaka članica prema čl. 11 ima i „prijateljsko“ pravo upozoriti Skupštinu ili Vijeće na „svaku okolnost u međunarodnim odnosima koja predstavlja prijetnju miru ili dobrim odnosima među narodima u pitanju. “24 Ukoliko bi se pak država članica odlučila na rat ne obazirući se na mehanizam očuvanja mira temeljen na kolektivnoj sigurnosti, njezina objava rata bi se posljedično smatrala objavom rata drugim članicama Lige, što im sukladno čl. 16 kao „kaznenom zakoniku Lige naroda“ daje pravo poduzimanja različitih vrsta sankcija prema prekršitelju. ${ }^{25}$ lako utemeljen na pretpostavci reciprociteta te zajedničkog djelovanja određenog prethodno usvojenim standardom ili normom, sigurnosni mehanizam Lige određeni je automatizam predviđao u primjeni ekonomskih i kulturnih sankcija, dok je upotrebu vojnih snaga protiv prekršitelja Liga mogla tek preporučiti članicama, tj. konačna odluka kako postupati počiva na svakoj državi-članici. Navedeno rješenje, koje Sharp drži samom srži svih kasnijih neuspjeha Lige, odudara od ranijih prijedloga nacrta njezine Povelje koji su predviđali obvezatni i kolektivni odgovor država-članica. Navedeno rješenje je u konačnici odbačeno jer se smatralo da je takvo opće i a priori jamstvo protivno pravu članica da, kao suverene države, odlučuju o pitanjima rata i mira. ${ }^{26}$ Ukoliko sve poduzete mjere ne bi urodile plodom, preostala bi mogućnost da se ratoborna država izbaci iz članstva Lige naroda. ${ }^{27}$

23 Tako A. ALCOCK, A History of the Protection of Regional Cultural Minorities in Europe, 53.

24 Poštivajući suverenitet države-članice, pobune, nemiri itd. već se stilizacijom članka 10 implicitno smatraju njezinim unutrašnjim pitanjima nad kojima Liga nema nadležnost. Vidi i G. STRUIĆ, n. dj., 204.

25 Vidi D. LAPAŠ, Sankcija u međunarodnom pravu, 199-206. Lapaš sistematizira sankcije Lige na sankcije bez upotrebe sile, sankcije s upotrebom sile pomoću kopnenih, pomorskih i zračnih snaga država članica i disciplinske sankcije isključenja države iz članstva Lige.

26 Izostanak jasne obveze upotrebe sile protiv prekršitelja pravdano je dostatnošću moralno nadmoćnih zahtjeva Lige u sprječavanju (i oružanog) sukoba. Prilikom rasprave o nacrtu Povelje pojedini delegati bili su svjesni da je navedeni ustupak učinjen uslijed nedostatka političke spremnosti velikih sila da preuzimu ovakvu obvezu. Vidi detaljnije A. SHARP, n. dj.; G. STRUIĆ, n. dj., 202-203.

27 Time bi se narušio međunarodni ugled te države, ali faktično ona više ne bi bila vezana (ipak!) ograničenjima koja su bila sadržana u Povelji Lige. Također, ratoborna država, uz ostale međunarodne ugovore kojih je članica, bila bi i dalje vezana tadašnjim načelima i pravilima općeg (običajnog) međunarodnog prava (op.a.). 
Stilska neodređenost članka 16 u pogledu primjene zaštitnog mehanizma prouzročit će izvjesne dvojbe, ne samo u pogledu spora države članice s nečlanicom Lige, što 1921. godine dovodi do osnivanja Međunarodne komisije za blokadu, čije će prijedloge Skupština Lige u dobroj mjeri uvažiti. ${ }^{28}$

\section{Posljedice Versajskog mirovnog ugovora na europsku sigurnost}

U mirovnim ugovorima jasno su uočljivi političko-ekonomski motivi kojima su se vodile pobjedničke sile. Uz smanjivanje teritorija poraženih država, čime se stvaraju velike njemačke i mađarske manjine, mirovnim se ugovorima nastoji ograničiti njihova ekonomska snagu. Ekonomski kapaciteti gubitnica ne samo da trebaju pogodovati pobjednicama, nego su podredno zamišljeni i kao dodatno sredstvo umanjenja njihove vojne moći, sprječavajući tako potencijalni budući oružani sukob. Za razliku od odredbi potpisanog primirja, mirovnim ugovorima se obuhvaća sva nastala štetu koju su Njemačka i druge poražene države, kao krivci za izbijanje rata, dužni u potpunosti platiti. ${ }^{29}$ Istovjetne odredbe glede odgovornosti za rat sadrže i ugovori iz Saint-Germaina u čl. 117., ugovor iz Trianona u čl. 161., te donekle različite formulacije, ali istog efekta i ugovor iz Neuillya ${ }^{30}$ iako ovaj ugovor u čl. 121. određuje fiksnu sumu reparacija. ${ }^{31}$ Posebno su oštre odredbe mirovnog ugovora s Turskom kojim se uz reparacije zakonskom regula-

28 Tako D. LAPAŠ, Sankcija u međunarodnom pravu, 203-204. Vidi i Miran MARELJA, The World War One Peace Treaties as the source of rights or obligations for the non-parties, EKOB 2018 - Economy in Transformed Security Environment, Center for Security, Management and International Politics, str. 149-150.

29 Pri čemu, ukoliko uvažimo Wilsonove zamisli, demokratska Weimarska Republika nije se niti mogla smatrati neprijateljem. Odgovornost Njemačke za početak rata je i danas sporna među povjesničarima. Zagovornici njemačke odgovornosti u pravilu navode agresivnu njemačku vanjsku politiku suprotstavljanja Britaniji izgradnjom mornarice te Francuskoj u pogledu Maroka. U prilog ovakvom promišljanju govore i njemačke težnje ka širenju na Istok, s obzirom da je od svih njemačkih susjeda Rusko Carstvo bilo u očiglednom ekonomskom i vojnom zaostatku. Njemački vanjskopolitički ciljevi će biti formulirani 1914. godine u tzv. Rujanskom programu koji je predviđao ujedinjenje s Austrijom, uz teritorijalna proširenja Njemačke na Nizozemsku, Belgiju i Poljsku. Susjedne države koje bi i ostale izvan buduće Njemačke države bile bi uključene u vrstu ekonomske unije s Njemačkom, čime bi se Francuska dodatno oslabila. Vidi N. A. GRAEBNER, E. M. BENNETT, The Versailles Treaty and Its Legacy: The Failure of the Wilsonian Vision, 48.

30 Iznos bugarskih reparacija iznosit će 2,25 milijardi zlatnih franka.

31 Slično i ugovorom iz Sèvresa u čl. 231. Bugarska i Turska se obvezuju na kompletne reparacije pri čemu se konstatira da one to u trenutku potpisivanja sporazuma nisu u mogućnosti, no imputira se njihova odgovornost sekundarne prirode, tj. pri udruživanju i pomaganju Njemačkoj i Austro-Ugarskoj u vođenju rata. Ovakva stilizacija, ukoliko prihvatimo sporno tumačenje čl. 231. Versajskog ugovora o krivnji za rat, još jednom indirektno ukazuje da je primarna odgovornost za vođenja rata na strani raspale Austrougarske monarhije i Njemačke. Vidi Sally MARKS, "The Myths of Reparations", Central European History, sv. 11, br. 3, 1978., 231-255. 
IVAN OBADIĆ, MIRAN MARELJA: Pitanje europske kolektivne sigurnosti u razdoblju od ...

cijom znatno sputava njezin ekonomski život, prvenstveno kontrolom nad turskim budžetom te posebno prestrukturiranjem Imperijalne banke u korist zemalja pobjednica. Ipak, raspadom Turskog Carstva i Austro-Ugarske postaje jasno da se jedino od Njemačke može osigurati značajniji iznos na ime reparacija. Kako je pak Njemačka i sama iscrpljena ratom, ne postoji mogućnost kompenzacije ratne štetu za koju je pobjednice drže odgovornom, ${ }^{32}$ pa se predviđa naknadno utvrđivanje točnog iznosa reparacija. ${ }^{33}$ Vidljiva je i težnja saveznica da se ogromnim iznosima reparacija onemogući gospodarski rast pobijeđenih država čime bi ih se uz element kažnjavanja dodatno onemogućilo u stvaranju ekonomske snage potrebne za izazivanje nekog budućeg sukoba. Ipak, nastojala se pronaći ravnoteža između težnji da se šteta nastala ratom u što većoj mjeri prebaci na Njemačku dok s druge strane iznos reparacija nije smio biti takav da ga ova država ne bi mogla platiti.

Ugovori tek privremeno uređuju pitanje reparacija ostavljajući konačno rješenje za neki kasniji međunarodni instrument, no zato sa znatno više pažnje pristupaju uspostavi mehanizama nadzora ekonomskog života poraženih država, dijelom i kroz nametanje slobode prometa teritorijem poražene države kroz internalizaciju odnosnog teritorija, čime se ukida suvereno pravo poražene države da na svom vlastitom teritoriju samostalno uređuje ova pitanja. Međutim, rješenja predviđena Versajskim ugovorom koja su trebala teritorijalno, vojno i ekonomski oslabiti Njemačku, a istovremeno osigurati Francuskoj ekonomske beneficije kojima bi obnovila svoje financije i ubrzala ekonomski razvoj, nisu bila dugoročno održiva. ${ }^{34}$ Naime, uz njemačke teritorijalne ustupke, ograničavanje vojne sile, lišavanje bivših prekomorskih kolonija, nametanje moralne odgovornosti za rat i sve njegove posljedice (tzv. klauzula o ratnoj krivici), najvažnija pita-

32 Čl. 231. Sporna formulacija ove klauzule zapravo predstavlja temelj za pitanje dogovornosti za prouzročenu štetu nastalu njemačkom agresijom, tj. štetu nastalu protupravnim njemačkim djelovanjem pri čemu se izravno ne navodi odgovornost za izbijanje rata, kako će se ova klauzula kasnije tumačiti. Zanimljivo da se istovjetne odredbe Trianonskog ugovora i ugovora iz Saint-Germana nisu prikazivale kao mađarsko i austrijsko priznanje odgovornosti za rat . Vidi detaljnije u S. MARKS, isto., 231. i 232.

33 Čl. 232. i 233. Versajski ugovor traži isplatu od 20 milijardi maraka do 1. svibnja 1921. godine pri čemu konačni iznos ostaje neodređen. Ukupan iznos (ukupnih) reparacija na ime naknade štete bit će Londonskim ugovorom postavljen na 132 milijarde njemačkih maraka što bi okvirno odgovaralo današnjih 418 milijardi US \$. Od ovog iznosa na Njemačku je (kroz A i B seriju obveznica) otpadalo oko 50 milijardi tadašnjih maraka uz 37 milijardi za dodatne troškove pobjednica. Uz godišnju ratu od 2 milijarde predviđalo se da će Njemačka svoj dug s kamatama isplatiti 1987. godine obzirom da je šteta pokrivala i trošak dijela mirovina vojnika država pobjednica. Njemačka je posljednju ratu u iznosu od 69.9 milijuna € platila 3. rujna 2010. g. Isto, 238.

34 P. CLAVIN, n. dj., 515-520. 
nja na Pariškoj mirovnoj konferenciji za francusku stranu su uz pitanje reparacija bila repozicioniranje industrije ugljena i čelika između Francuske, Belgije i Njemačke. ${ }^{35}$ Upravo je Prvi svjetski rat potvrdio važnost vojno-industrijskog kompleksa, a osobito odlučujuću ulogu snažne industrije čelika u modernom ratovanju. Stoga je Versajski sporazum sadržavao, kako Bariety ističe, novu organizaciju proizvodnje čelika i energije u europskim okvirima koja je uključivala vraćanje pokrajina Alsacea i Lorraine Francuskoj, područja Eupen-Malmédyja Francuskoj i Belgiji, dok je Saarski bazen predan na upravljanje Društvu naroda na razdoblje od petnaest godina (tzv. Saarsko područje), s time da je jedino Francuska imala pravo eksploatacije rudnika ugljena. ${ }^{36}$

Francuska je balansirala između sve neodređenijeg savezništva s dojučerašnjim saveznicama, dijelom i radi njihovog financiranja ekonomskog oporavaka u ratu iznurene Francuske, i s druge strane inzistiranja (pa i unilateralnog) na poštivanju odredbi Versajskog mirovnog sporazuma s Njemačkom, poput za Francusku vitalnih odredbi o posebnom statusu Rajnske oblasti kako bi se onemogućio ili barem znatno otežao oporavak njemačke ekonomske i vojne moći, a time i osujetilo uzdizanje Njemačke kao velike sile. ${ }^{37}$ Francuskoj nepopustljivosti doprinosi rasplamsavanje međunarodne debate o primjerenosti uvjeta mirovnog ugovora, tj. jesu li trebali biti još stroži ili je pak ugovor trebao biti blaži, odnosno jesu li trebali u znatno većoj mjeri odražavati Wilsonove ideje. ${ }^{38}$ Očekivano, debatu prate konsilijatorni tonovi demokratske Weimarske Njemačke koja će, suočena s teškom gospodarskom situacijom, početi kliziti u hiperinflaciju kako bi anulirala unutrašnji dug, usput žrtvujući siromašni i srednji sloj u korist jačanja krupnog kapitala u kojem vidi temelj budućeg gospodarskog rasta. Politički izolirana i pod vanjskopolitičkim pritiskom Francuske, Njemačka očajnički pokušava ojačati svoju poziciju u međunarodnim odnosima, tražeći potporu na naizgled neočekivanom mjestu - Sovjetskom Savezu, kao sili podjednako ostraciziranoj od strane pobjedničkog bloka zapadnih zemalja. Nakon što boljševička vlast odustane od

35 Od sredine 19. stoljeća proizvodnja ugljena i čelika predstavljala je temelj industrijske i vojne moći.

36 Jacques BARIÉTY, „France and the Politics of Steel, From the Treaty of Versailles to the International Steel Entente, 1919-1926", French Foreign and Defence Policy, 1918-1940, Routledge, gl. ur. Robert BOYCE, London - New York, 1998., 33-34.

37 Jon JACOBSON, "Strategies of French Foreign Policy after World War I", The Journal of Modern History, sv. 55, br. 1, 1983., 85.

38 Feldman ironično navodi da su ,jedini ljudi koji su ikad vjerovali kako Njemačka može platiti traženi iznos bili pojedini povjesničari, ... a i takvih je sve manje.“ Gerald D. FELDMAN, „Comment“, The Treaty of Versailles: A Reassessment after 75 Years, Cambridge University Press, gl. ur. Manfred F. BOEMEKE, Geralrd D. FELDMAN, Elisabeth GLASER, Cambridge, 1998., 445. 
IVAN OBADIĆ, MIRAN MARELJA: Pitanje europske kolektivne sigurnosti u razdoblju od ...

izravnog pozivanja na svjetsku revoluciju, Rapalskim ugovorom 1922. godine ove dojučerašnje ratne suparnice grade svojevrsni modus vivendi. ${ }^{39}$

Neodrživost francuske pozicije započinje već odbacivanjem ratifikacije mirovnog ugovora od strane američkog Senata i povratka SAD-a izolacionizmu umjesto Wilsonove koncepcije vanjske politike i sustava međunarodnih odnosa izloženih u programu Četrnaest točaka, što ubrzo prati britansko odbijanje unilateralnih vojnih jamstava, jer bi sasvim izgledno na njezinu mornaricu pao teret provedbe ekonomskih sankcija u ime Lige, kao i rastuća zaokupljenost Velike Britanije vlastitim imperijalnim ambicijama. Francuski odnosi s Velikom Britanijom bili su opterećeni i britanskim sumnjama da Pariz teži uspostavljanju francuske hegemonije u Europi koja bi poremetila europsku ravnotežu snaga. Uz to, SAD i Velika Britanija su u želji sprječavanja sasvim izgledne boljševičke revolucije u Njemačkoj smatrale da se ova država mora što prije rehabilitirati te ekonomski i politički stabilizirati. Nakon sovjetsko-njemačkog približavanja Rapalskim ugovorim 1922. godine, ove bojazni na Zapadu jačaju, pri čemu i sama Francuska postaje svjesna kako ekonomska obnova Europe je nemoguća bez njemačkog gospodarskog oporavka. ${ }^{40}$ Umjesto Rusije, i bez angloameričkih sigurnosnih garancija, Pariz je svoje nade polagao na vojno slabije novonastale istočnoeuropske države, Poljsku i države tzv. Male Antante, a u kojima je vidio dvostruku branu protiv sovjetske opasnosti s istoka i njemačke u Srednjoj Europi. ${ }^{41}$

Uz pitanje teritorijalne revizije i uklanjanja vojnih restrikcija, reparacije su predstavljale ključno pitanje koje je od samog početka izazivalo napetosti ne samo između Njemačke i Francuske, već i između Francuske i njezinih angloameričkih saveznika. Pa dok se na Londonskoj konferenciji 1921. godine utvrđuje ukupan iznos ratne odštete, suprotno očekivanjima situacija eskalira nakon što Njemačka u jesen 1922. odluči izbjeći isplatu godišnje reparacijske rate. Kako francuski premijer Raymond Poincaré inzistira na bespogovornom njemačkom ispunjenju versajskih obveza uslijedit će francusko-belgijska okupacija Ruhra kao

39 Osim svojevrsnog izlaska iz izolacije za obje zemlje, razvija se i ekonomska suradnja dok će Sovjetski Savez biti od presudne važnosti za očuvanje vojne spremnosti njemačke vojske.

40 Britansku politiku je objasnio Churchill koji je zatražio „izgradnju jake, ali miroljubive Njemačke, koja neće napadati naše francuske saveznike, ali će istovremeno djelovati kao moralni bedem protiv boljševika" i tako "izgraditi nasip miroljubive, zakonite, strpljive snage i vrline protiv poplave crvenog barbarstva koje pritječe s Istoka". Cit. prema Brendan SIMMS, Europa: Borba za nadmoć od 1453. do danas, MATE, Zagreb, 2016., 283.

41 Mala Antanta je bila obrambeni savez Čehoslovačke, Kraljevine SHS i Rumunjske formiran 1920. godine protiv revizionisitičkih pretenzija Mađarske i Rumunjske. Rene LOVRENČIĆ, R., Nemirni mir, Mala zvona, Zagreb, 2011., 83. Vidi i A. E. ALCOCK, A History of the Protection of Regional Cultural Minorities in Europe, 53. 
industrijskog srca Njemačke 1923. godine i izravna eksploatacija prirodnih, posebice rudnih bogatstava kojima je ovaj kraj bogat (okupacija će trajati sve do 1925. godine) ${ }^{42}$ Dok će se okupacija formalno predočiti kao zahtjev za ispunjavanje reparacijskih obveza, ovaj čin je ujedno i francuski odgovor na rastući njemački revizionizam kojeg prate sve glasniji zahtjevi za ublažavanjem odnosno dokidanjem pojedinih odredbi mirovnog ugovora. ${ }^{43}$

lako je Francuska uspjela slomiti njemačku politiku pasivnog otpora, okupacija izaziva val oštrih kritika u Europi i Americi te narušava već načete francusko-britanske odnose. Rurska kriza jasno ukazuje na ograničene političke domete unilateralnih postupaka kojima je Francuska težila osigurati provedbu odredbi Versajskog mirovnog ugovora te da, za razliku od Francuske, kod ostalih pobjednica postupno slabi revanšizam. ${ }^{44}$ Kako Londonska konferencija predstavlja pomak, ali ne donosi sveobuhvatno rješenje pitanja reparacija, modalitet isplate se pokušava dogovoriti 1924. godine Dawesovim planom; uz američko kreditiranje njemačke privrede uzimaju se u obzir njemački financijski problemi pri isplati godišnjih rata, no plan će donijeti tek polovična rješenja. ${ }^{45}$ Dodatno, francuski unilateralni čin dovest će u pitanje ulogu Lige u očuvanju svjetskog mira, što prate pokušaji pojedinih diplomata i državnika poput lorda Cecila i predsjednika Beneša koji su željeli osnažiti kapacitete Lige pomoću jasnijih obveza država članica, što su trebali osigurati Ugovor o međusobnoj pomoći iz 1923., a potom i Ženevski protokol iz 1924. godine. ${ }^{46}$ Dok Ugovor izrijekom napadački rat kvalificira kao međunarodni zločin, jačajući pri tome kapacitete Vijeća Lige za njegovo sprječavanje i suzbijanje, Ženevskim se protokolom pokušalo ipso facto označiti

42 Nemogućnost Njemačke da izvrši svoje obveze uslijed inflacije ukazuje na ekonomsku krhkost tadašnje Weimarske republike. Francuska pak drži da je njemačka nemogućnost izvršenja preuzetih obveza namjerno prouzročena, jer se hiperinflacija ciljano potiče. Kancelar Wirth je njemački problem sažeo u slogan: „Prvo kruh, a onda reparacije“, kojeg će pak kasnije preuzeti Nacionalsocijalistička njemačka radnička stranka. Vidi Conan FISCHER, „The Human Price of Reparations“, Diplomacy \& Statecraft, sv. 6, br. 3, 2005., 504.; S. MARKS, n. dj., 243.

43 Čedomir POPOV, Od Versaja do Danziga, Nolit, Beograd, 1976, 144-145; Zara STEINER, The Lights That Failed: European International History 1919-1933, Oxford University Press, Oxford - New York:, 2005., 414-415.

44 J. JACOBSON, n. dj., 85; Edward D. KEETON, „Economics and Politics in Briand's German Policy“, German nationalism and the European response, 1890-1945, University of Oklahoma Press, gl. ur. Carole FINK, Isabel V. HULL, MacGregor KNOX), 1985, 162. Više o pitanju provedbe Versajskog mirovnog sporazuma vidi u Alan SHARP, „The Enforcement of the Treaty of Versailles, 1919-1923“, Diplomacy \& Statecraft, sv. 16, br. 3, 423-438.

45 Vidi i Roland PORTMANN, Legal Personality in International Law, Cambridge, Cambridge University Press, 2010., 229.

46 Tako Sharp, op. cit. 
IVAN OBADIĆ, MIRAN MARELJA: Pitanje europske kolektivne sigurnosti u razdoblju od ...

agresorom svaku državu-članicu koja bi odbila prihvatiti arbitražu Stalnog suda međunarodne pravde. ${ }^{47}$

\section{UGOVORI IZ LOCARNA KAO RJEŠENJE PITANJA EUROPSKE SIGURNOSTI?}

Pošto Njemačka nije bila članica Lige naroda, postojale su znatne nedoumice i praktične poteškoće u adaptaciji sigurnosnog mehanizma Lige na pogoršane odnose Pariza i Berlina. Povelja Lige uređuje u čl. 17 problematiku sporova država članica s nečlanicama odnosno između država nečlanica, pri čemu se predviđeni mehanizam rješavanja sporova teži proširiti i na države nečlanice, uslijed svijesti delegata Mirovne konferencije da su određene države poput Njemačke ili boljševičke Rusije isključene iz članstva u Ligi. ${ }^{48}$ Štoviše, pojedine države su se tretirale kao neprijateljske države u odnosu na članice Lige, dok druge iz različitih razloga nisu pristupile Ligi naroda te je bilo potrebno omogućiti im upotrebu sigurnosnog mehanizma, no ako to učine dužne su prihvatiti sve obveze koje proizlaze članstva u Ligi naroda. ${ }^{49}$ Dakle, u pitanju je pravo koje država nečlanica može koristiti, ali pod uvjetom da prethodno prihvati članske obveze članice Lige za vrijeme spora, pri čemu sama inicijativa ne leži na državi nečlanici, već na Ligi naroda. ${ }^{50}$ Ukoliko bi se država nečlanica oglušila na poziv Lige za posredovanjem te pribjegla oružanom sukobu, prevladavalo je tumačenje čl. 17. da bi takav čin ujedno značio objavu rata svim članicama Lige. ${ }^{51}$ Ipak, navedeno tumačenje moglo se odbaciti obrazloženjem kako je u pitanju ponuda Lige državi nečlanici te samo u slučaju prihvata ponude može doći do djelovanja odredbi u korist trećeg. ${ }^{52}$ Nametanje sigurnosnog mehanizma Lige naroda državama nečlanicama, kao i pratećih obveza na određeno postupanje pod prijetnjom sankcije nije imalo uporišta u (tadašnjem) međunarodnom pravu. Stoga, iako će sigurnosni

47 Tekst prijedloga Ugovora o međusobnoj pomoći iz 1923. godine dostupan u World Peace Foundation, Pamphlet Series, sv. 480, 1924., 480-487. Tekst prijedloga Protokola o mirnom rješavanju međunarodnih sporova iz 1924. godine dostupan u J. T. Shotwell (ur.), International Conciliation, sv. 10, 1924., 531-543.

48 Povelja Ujedinjenih naroda također sadrži odredbu o neprijateljskim državama, referirajući se pritom na sile gubitnice u Drugom svjetskom ratu. Vidi tako čl. 53, 77 i 107 Povelje Ujedinjenih naroda, NNMU, br. 15, 1993.

49 Vijeće Lige naroda je moglo u konkretnoj situaciji obveze članstva u Ligi adaptirati kako bi bile „pravične" u odnosu na državu nečlanicu, za vrijeme trajanja spora. Nakon prihvata, Vijeće Lige bi trebalo istražiti okolnosti spora i predložiti rješenje. Vidi i Susan PEDERSEN, „Back to the League of Nations“, The American Historical Review, sv. 112, br. 4, 2007., 1093-1099.

50 Vidi Budislav VUKAS, Relativno djelovanje međunarodnih ugovora, Zagreb, Školska knjiga, 1975., 121.

51 Odnosno čl. 16. i s njim u vezi čl. 11. u slučaju kada je u pitanju članica Lige.

52 B. VUKAS, Relativno djelovanje međunarodnih ugovora, 121; M. MARELJA, , n. dj., 149-150. 
mehanizam Lige naroda uspješno riješiti sporove Švedske i Finske 1920., Grčke i Bugarske 1925. te Turske i Velike Britanije odnosno Turske i Irana 1926. godine, nepremostiva prepreka kolektivnoj sigurnosti u Europi predstavljala je rečena antagonizacija bilateralnih odnosa Francuske i Njemačke. ${ }^{53}$ Postalo je jasno da (održivo) rješenje cijelog niza otvorenih pitanja u odnosima ovih dviju država može donijeti tek sustavni kompromis, koji nužno traži nadilaženje rješenja iz odredbi Versajskog mirovnog ugovora. ${ }^{54}$

Negativni odjeci francuske okupacije Ruhra će u konačnici dovesti do ostavke Poincaréa na mjesto predsjednika francuske vlade 1924. godine i povratka Brianda na položaj ministra vanjskih poslova iduće godine. Slom sistema angloameričkih sigurnosnih garancija Francuskoj i neuspjeh Pariza da barem osigura formalne sigurnosne aranžmane sa Velikom Britanijom, ozbiljne nedoumice u francuskim vladinim krugovima o stvarnoj vrijednosti saveza s istočnoeuropskim zemljama u pogledu ograničavanja njemačke moći i utjecaja, visoki diplomatski i ekonomski troškovi unilateralne provedbe odredbi mirovnih ugovora, utjecat će na Briandovo odbacivanje dotadašnje rigidnosti francuske politike te deeskalaciji napetosti između dvije države i promicanju politike europske suradnje kao jamstva mira i stabilnosti europskog poretka. ${ }^{55}$ Naime, Briand je bio svjestan da je Njemačka ekonomska i vojna moć možda bila sputana Mirovnim sporazumom i odredbama o slabljenju njemačke industrije ugljena i čelika u korist Francuske i Belgije, no ekonomske prednosti u francusku korist bile su tek privremene prirode, a pokazat će se i nedovoljne uslijed silovitog ekonomskog oporavka Njemačke početkom 20-ih godina. ${ }^{56} \mathrm{Na}$ Londonskoj konferenciji 1924. godine Francuska prihvaća brojne koncesije u korist Njemačke, a u konačnici i Dawesov plan koji ne samo da okončava francusko-belgijsku okupaciju Ruhra nego i olakšava isplatu njemačkih ratnih reparacija. Njemačka je pak bila spremna održati status quo na svojim zapadnim granicama, dok iste garancije nije bila spremna dati za svoje istočne granice, zbog čega će francuska vlada sklopiti poseban sporazum sa Poljskom i Čehoslovačkom kojim je željela institucionalizirati tzv. istočni Locarno u europsku sigurnosnu arhitekturu.

Na ovim postavkama 1925. godine dolazi do sklapanja Locarnskih ugovora kojima su Njemačka, Francuska, Belgija, Velika Britanija i Italija jamčile nepovre-

\footnotetext{
53 F. LANDRY, „Evolution of collective security“, The ILSA Quarterly, sv. 20, br. 3, 2012., 91.

54 Članak 19. Povelje Lige naroda, kao sastavni dio svih mirovnih ugovora, predviđao je mogućnost izmjene „ugovora koji su postali neprimjenjivi“, uzimajući u obzir „međunarodne prilike čiji bi nastavak mogao ugraziti svjetski mir."

55 Č. POPOV, Od Versaja do Danziga, 144-145; Z. STEINER, The Lights That Failed: Steiner, 414-415.

56 J. JACOBSON, n. dj., 79.
} 
IVAN OBADIĆ, MIRAN MARELJA: Pitanje europske kolektivne sigurnosti u razdoblju od ...

divost granica određenih Versajskim mirovnim ugovorom, a donesena je i odluka da se Njemačka primi u Ligu naroda, što će se iduće godine i ostvariti. ${ }^{57}$ Ugovori iz Locarna predstavljaju kompromis kojim se izglađuju glavni prijepori te konačno uspijevaju Versajski mirovni ugovor učiniti prihvatljivim i ratnim pobjednicama Francuskoj i Velikoj Britaniji, ali i gubitnici Njemačkoj. Kompromis je bio moguć jer ugovorima jača i položaj Francuske uslijed izglađivanja prijepora u odnosima s Velikom Britanijom, kojoj pak odgovara stabilizacija odnosa među zapadnoeuropskim državama radi ekonomskog oporavka i konsolidacije njezinog kolonijalnog carstva. ${ }^{58}$ Ovi su ugovori prema riječima britanskog ministra vanjskih poslova Austena Chamberlaina, uvelike zaslužnog za njihovo sklapanje, označili „stvarnu liniju razdvajanja između godina rata i godina mira koje sada slijede".59

Locarnski sporazumi u velikoj mjeri doprinose nadvladavanju nepovjerenja između Francuske i Njemačke, koja pak ovim sporazumima uspijeva u dijelu revidirati odredbe mirovnog ugovora, prije svega kroz korekciju istočnih granica Njemačke, ranijeg povlačenja savezničkih snaga iz demilitariziranog Rajnskog područja, ublažavanja reparacija te ukidanja savezničkog nadzora nad njemačkim vojnim snagama. ${ }^{60}$ Iza francuske politike deeskalacije sukoba i približavanja Njemačkoj stoje također i ekonomski razlozi jer već sredinom 1920-ih godina postaje jasna neodrživost poticanja francuskih tvrtki da ulažu u zemlje istočne Europe, tj. na tržišta od sporedne važnosti za francusku ekonomiju. ${ }^{61}$ Ova politika izazivala je sve veći otpor financijskih i industrijskih krugova koji su inzistirali da se Francuska mora više orijentirati na njemačko tržište te na sklapanje trgovinskog sporazuma sa Njemačkom, tim više što je prema odredbama mirovnog ugovora bescarinski ulazak francuske robe na njemačko tržište bio zajamčen samo do 1925. godine. Nakon tri godine pregovaranja, Francuska i Njemačka zaključile su 1927. godine sveobuhvatan trgovinski sporazum. Ovim sporazumom su trgovinski i gospodarski odnosi sa Njemačkom postali od krucijalne važnosti za

57 Patrick O. COHRS, "The Quest for a New Concert of Europe: British pursuit of German Rehabilitation and European Stability in the 1920s", Locarno Revisited: European Diplomacy 1920-1929, Routledge, gl. ur. Gaynor JOHNSON, London - New York, 2004, 35.

58 Vidi isto, 38-50.

59 Tako Jonathan WRIGHT, "Locarno: a democratic peace?", Review of International Studies, sv. 36, br. 2, 2010., 402.

60 Iza njemačkih napora stoji Gustav Stresemann, gorljivi njemački nacionalista koji je nakon Prvog svjetskog rata postao liberal i republikanac, shvativši kako je njemačka revizionistička politika doživjela neuspjeh te da daljnja konfrontacija može biti kobna za opstojnost Njemačke. Vidi detaljnije Jonathan WRIGHT, "Stresemann: A Mind Map", u: Locarno Revisited: European Diplomacy 1920-1929, Routledge, gl. ur. Gaynor JOHNSON, London - New York, 2004, 151-158.

61 Vidi KEETON, n. dj., 164-166. 
francusku ekonomiju. ${ }^{62}$ Godinu dana prije nego je sklopljen „ekonomski Locarno", francuski, njemački i belgijski proizvođači čelika sklopili su Međunarodni sporazum o čeliku kojom su razriješeni problemi koji su proizlazili iz Versajskog mirovnog ugovora i koja se održala sve do početka Drugog svjetskog rata. ${ }^{63}$ Slični sporazumi su sklopljeni i u ostalim granama industrije.

Locarno dakle predstavlja početak smirivanja situacije u Zapadnoj Europi i izgradnje, doduše kratkoročno, stabilnijih međunarodnih odnosa u Europi. Francuskim političkim krugovima su slabosti europskog sustava sigurnosti uspostavljenog Locarnskim sporazumima bila očigledne. Naime, iako je Njemačka uključena u sustav kolektivne sigurnosti, pitanje istočnih granica ostalo je i dalje otvoreno. ${ }^{64}$ Locarnski sporazumi su doveli i do ublažavanja odredbi Versajskog mirovnog ugovora pa 1927. godine Liga naroda ukida savezničku Komisiju za kontrolu njemačkog naoružanja, dok su na Konferenciji o likvidaciji rata u Haagu 1929. zapadne sile Youngovim planom pristale revidirati Dawesov plan i smanjiti iznos njemačkih reparacija te pet godina prije roka završiti okupaciju Rajnske oblasti (1930. godine). ${ }^{65}$ Francuski napori za jačanjem sustava jamstava i kolektivne sigurnosti dovest će i do tzv. Briand-Kelloggovog pakta koji je u Parizu potpisalo petnaest zemalja, uključujući Veliku Britaniju i Njemačku. lako se njegovim odredbama odbacuje rat kao sredstvo ostvarenja političkih ciljeva, Pariški pakt nije bio učinkovit međunarodnopravni instrument uslijed odsustva sustava za rješavanje sporova i prevenciju konflikata, kao i kolektivne sankcije onih država koje bi kršile njegove odredbe. ${ }^{66}$

\section{ZAKLJUČAK}

Stabilizacijom poslijeratnog europskog poretka započinje opći europski detant, čemu su pogodovala i opća društveno-ekonomska i politička kretanja u Europi. Nakon 1923. godine europske ekonomije su se počele oporavljati od teških posljedica Prvog svjetskog rata. Izlazak iz ekonomske krize stabilizirao je političke prilike u europskim društvima koja su se neposredno nakon rata zbog teške ekonomske i socijalne situacije našle na rubu građanskog rata i revolucije. Smi-

\footnotetext{
62 Tako Cornelia NAVARI, "The Origins of the Briand Plan”, Diplomacy \& Statecraft, sv. 10, br. 1, 1980, 77.

63 J. BARIÉTY, n. dj., 41-44.

64 John KEIGER, „Poincaré, Briand and Locarno: Continuity in French Diplomacy in the 1920s“, Locarno Revisited: European Diplomacy 1920-1929, Routledge, gl. ur. Gaynor JOHNSON, London - New York, 2004, 98-102.102-103.

65 Ian KERSHAW, Do pakla i natrag. Europa 1914.-1949., Fraktura, Zagreb, 2017., 194-195.

66 G. STRUIĆ, n. dj., 206.
} 
rivanje političke situacije istovremeno je učvrstilo parlamentarne poretke koji su uspostavljeni diljem Europe nakon propasti autoritarnih carstava, s iznimkom Mađarske, Španjolske i Italije, a upravo su demokratske vlade bile glavni jamac europskog mira. ${ }^{67}$ Ekonomski prosperitet, društveno-politička stabilizacija i konsolidacija demokracije su stvorile atmosferu optimizma i nade da Europa može krenuti putem mira i napretka.

Locarnski sporazumi će otvoriti mogućnost stvaranja stabilnog poslijeratnog europskog poretka u okviru kojeg bi se riješili temeljni problemi europske sigurnosti. Ujedno je po prvi puta u povijesti otvorena mogućnost europskim državama da ostvare političku i ekonomsku integraciju Europe mirnim putem. Naime, 1929. godine, u završnoj fazi europskog detanta, Aristide Briand će predložiti stvaranje Europske unije. Briandov plan za stvaranje novih odnosa u Europi kroz uspostavu „jedne vrste federalne veze“ predstavljao je ustvari posljednji francuski pokušaj da se izgradi politički okvir za očuvanje europskog poretka koji je postignut sporazumima iz Locarna i time sačuva europski detant, a istovremeno osiguraju francuski geopolitički i ekonomski interesi. Briand će pri tom istaknuti i važnost ekonomske integracije europskih država, te da se europske ekonomije jedino zajednički kao jedan trgovinski blok mogu suprotstaviti rastućoj američkoj ekonomskoj snazi i njezinoj protekcionističkoj trgovinskoj politici. Francuska diplomacija smatrala je Youngov plan koji je trebao predstavljati „konačnu likvidaciju rata" kao pogodan trenutak da izađe pred europsku javnost sa svojom inicijativom.

Međutim, konačni dogovor glede pitanja reparacija pokazao se znatno težim nego što se očekivalo u francuskim vladinim krugovima, a rezerviran i ustvari negativan stav britanske i njemačke vlade prema Briandovom planu zapečatio je njegovu sudbinu. ${ }^{68}$ Naposljetku, u trenutku kada je Memorandum o ustroju Europske savezne unije predstavljen u svibnju 1930. godine, međunarodno raspoloženje se je drastično promijenilo. U listopadu 1929. godine izbila je velika ekonomska kriza koja je produbila političke podjele i potaknula jačanje nacionalizma i šovinizma. Radikalizacija političkih prilika posebno se osjetila u revizionističkim zemljama gdje je radikalna desnica naglo ojačala, prije svega u Njemačkoj koju je kriza najviše pogodila. Suočene sa krizom neviđenih razmjera, europske zemlje okrenule su se ekonomskom protekcionizmu koji će dodatno zaoštriti međudržavne odnose i izazvati animozitete među njima. Krhki europski poredak koji je

67 Ian KERSHAW, Do pakla i natrag. Europa 1914.-1949., 196-197.

68 Vidi više u Zrinka ERENT-SUNKO, Ivan OBADIĆ, Miran MARELJA, „Briandov plan: Prvi pokušaj stvaranja Europske unije (1929.-1932.), Zagrebačka pravna revija, Vol. 8, br. 3, 2018., 332-352. 
stabiliziran sredinom 1920-ih će se pod pritiskom ekonomskog kolapsa i rastućih političkih napetosti početi raspadati, što će na kraju završiti u još jednoj tragediji globalnog oružanog sukoba. Neuspjeh versajskog sustava kolektivne sigurnosti koji je predstavljao svojevrsnu institucionalnu nadgradnju ranijeg Europskog koncerta da odgovori na krizu europskog političkog i ekonomskog poretka, te strahovite posljedice Drugog svjetskog rata dovesti će do konačnog odbacivanja europskog sustava ravnoteže snaga, te traženja rješenja europske sigurnosti i političke stabilnosti kroz politiku europske integracije i otklanjanja nedostataka sustava kolektivne sigurnosti iz vremena Lige naroda.

\section{LITERATURA}

1/ Alan SHARP, „The Enforcement of the Treaty of Versailles, 1919-1923“, Diplomacy \& Statecraft, sv. 16, br. 3, 423-438.

2/ Alan SHARP, Collective Security, 2013., izvor dostupan na mrežnoj stranici: http://ieg-ego.eu/en/threads/alliances-and-wars/alliances-and-treaties/ alan-sharp-collective-security, posjećeno 15. studenog 2019. godine.

3/ Allen W. DULLES, "Collective security“, American Society of International Law Proceedings, sv. 33, 1939., 119-120.

4/ Antony Evelyn ALCOCK, A History of the Protection of Regional Cultural Minorities in Europe, Palgrave Macmillan, 2000., 43, 53.

5/ Brendan SIMMS, Europa: Borba za nadmoć od 1453. do danas, MATE, Zagreb, 2016., 283.

6/ Briand-Kellogov pakt, (27. kolovoza 1928. godine), dostupan na mrežnoj stranici https://avalon.law.yale.edu/-20th_century/kbpact.asp, posjećeno 20. rujna 2019. godine.

7/ Budislav VUKAS, Relativno djelovanje međunarodnih ugovora, Zagreb, Školska knjiga, 1975., 121.

8/ Conan FISCHER, „The Human Price of Reparations“, Diplomacy \& Statecraft, sv. 6, br. 3, 2005., 504.

9/ Cornelia NAVARI, "The Origins of the Briand Plan", Diplomacy \& Statecraft, sv. 10, br. 1, 1980, 77.

10/ Čedomir POPOV, Od Versaja do Danziga, Nolit, Beograd, 1976, 144-145.

11/ Davorin LAPAŠ, Sankcija u međunarodnom pravu, Pravni fakultet Sveučilišta u Zagrebu, Zagreb, 2004., 193-206.

12/ Edward D. KEETON, „Economics and Politics in Briand's German Policy“, German nationalism and the European response, 1890-1945, University of Oklahoma Press, gl. ur. Carole FINK, Isabel V. HULL, MacGregor KNOX, 1985., 162, 164-466. 
13/ Eric HOBSBAWM, Doba Extrema, Dereta, Beograd, 2002., 30-31.

14/ F. LANDRY, „Evolution of collective security“, The ILSA Quarterly, sv. 20, br. 3, 2012., 91.

15/ Gerald D. FELDMAN, „Comment“, The Treaty of Versailles: A Reassessment after 75 Years, Cambridge University Press, gl. ur. Manfred F. BOEMEKE, , Geralrd D. FELDMAN, Elisabeth GLASER, Cambridge, 1998., 445.

16/ Gordan STRUIĆ, „Kolektivna sigurnost i njezini mehanizmi u paktu Lige naroda", Pravni vjesnik, sv. 33, br. 3-4., 2017., 198-206.

17/ Ian KERSHAW, Do pakla i natrag. Europa 1914.-1949., Fraktura, Zagreb, 2017., 194-197.

18/ Immanuel KANT, Toward Perpetual Peace and Other Writings on Politics, Peace, and History, Yale University Press New Haven/ London, 2006., 67110.

19/ Jacques BARIÉTY, „France and the Politics of Steel, From the Treaty of Versailles to the International Steel Entente, 1919-1926", French Foreign and Defence Policy, 1918-1940, Routledge, gl. ur. Robert BOYCE, London - New York, 1998., 33-34, 41-44.

20/ John B. QUIGLEY, Soviet Legal Innovation and the Law of the Western World, Cambridge University press, Cambridge, 2007., 68-72.

21/ John KEIGER, „Poincaré, Briand and Locarno: Continuity in French Diplomacy in the 1920s", Locarno Revisited: European Diplomacy 1920-1929, Routledge, gl. ur. Gaynor JOHNSON, London - New York, 2004., 98-103.

22/ Jon JACOBSON, "Strategies of French Foreign Policy after World War I“, The Journal of Modern History, sv. 55, br. 1, 1983., 79, 85.

23/ Jonathan WRIGHT, "Locarno: a democratic peace?", Review of International Studies, sv. 36, br. 2, 2010., 402.

24/ Jonathan WRIGHT, "Stresemann: A Mind Map", u: Locarno Revisited: European Diplomacy 1920-1929, Routledge, gl. ur. Gaynor JOHNSON, London - New York, 2004., 151-158.

25/ Livia KARDUM, „Diplomatska borba za Korušku na Pariškoj mirovnoj konferenciji 1919. godine", Politička misao, sv. 38, br. 1, 2001., 126.

26/ Mark MAZOWER, Governing the World. The History of an Idea, Penguin Books, London, 2012, 3-12.

27/ Miran MARELJA, „The World War One Peace Treaties as the source of rights or obligations for the non-parties", EKOB 2018 - Economy in Transformed Security Environment, Center for Security, Management and International Politics, str. 149-150. 
28/ Norman A. GRAEBNER, Edward M. BENNETT, M., The Versailles Treaty and Its Legacy: The Failure of the Wilsonian Vision, Cambridge, Cambridge University Press, 2011., 35, 48.

29/ Patricia CLAVIN, „Reparations in the Long Run“, Diplomacy \& Statecraft, sv. 16, br. 3, 2005., 515-520.

30/ Patrick O. COHRS, "The Quest for a New Concert of Europe: British pursuit of German Rehabilitation and European Stability in the 1920s", Locarno Revisited: European Diplomacy 1920-1929, Routledge, gl. ur. Gaynor JOHNSON, London - New York, 2004., 35.

31/ Povelja Ujedinjenih naroda, NN-MU, br. 15, 1993.

32/ Protokol o mirnom rješavanju međunarodnih sporova iz 1924. godine, u J. T. SHOTWELL (ur.), International Conciliation, sv. 10, 1924., 531-543.

33/ Rene LOVRENČIĆ, R., Nemirni mir, Mala zvona, Zagreb, 2011., 83.

34/ Roland PORTMANN, Legal Personality in International Law, Cambridge, Cambridge University Press, 2010., 229.

35/ Rolf STEININGER, Austria, Germany, and the Cold War: From the Anschluss to the State Treaty 1938-1955, Berghahn Books, New York, Oxford, 2012., 1-4.

36/ Sally MARKS, „The Myths of Reparations“, Central European History, sv. 11, br. 3, 1978., 231-255.

37/ Susan PEDERSEN, "Back to the League of Nations“, The American Historical Review, sv. 112, br. 4, 2007., 1093-1099.

38/ Walter A. MCDOUGALL, „Political Economy versus National Sovereignty: French Structures for German Economic Integration after Versailles", The Journal of Modern History, vol. 51, br. 1., 1979., 4.-23.

39/ Wilson, W., Četrnaest točaka predsjednika Wilsona, tekst dostupan na web adresi: https://avalon.law.yale.edu/20th_century/wilson14.asp, posjećeno 20. rujna 2019.

40/ World Peace Foundation, Pamphlet Series, sv. 480, 1924., 480-487.

41/ Zara STEINER, The Lights That Failed: European International History 19191933, Oxford University Press, Oxford - New York:, 2005., 414-415.

42/ Zrinka ERENT-SUNKO, Ivan OBADIĆ, Miran MARELJA, „Briandov plan: Prvi pokušaj stvaranja Europske unije (1929.-1932.), Zagrebačka pravna revija, sv. 8, br. 3, 2018., 332-352. 


\section{SAŽETAK \\ PITANJE EUROPSKE KOLEKTIVNE SIGURNOSTI U RAZDOBLJU OD VERSAJSKE MIROVNE KONFERENCIJE DO UGOVORA IZ LOCARNA (1919.-1925.)}

U radu se analizira stvaranje i stabilizacija sustava europske kolektivne sigurnosti nakon završetka „Velikog rata“ do sredine 1920-ih godina, odnosno sklapanja ugovora iz Locarna. Na temelju literature i analize međunarodnopravnih dokumenata razmatra se izgradnja poslijeratnog svijeta na Pariškoj mirovnoj konferenciji, uspostavljanje sigurnosnog mehanizma temeljenog na kolektivnoj sigurnosti u okviru Lige naroda, te ugovore iz Locarna kao dopunu sustava kolektivne sigurnosti Lige naroda na europskoj razini.

Ključne riječi: Versajska mirovna konferencija; kolektivna sigurnost; Liga naroda; europska integracija; međunarodno pravo; ugovori iz Locarna.

\section{SUMMARY}

\section{THE ISSUE OF EUROPEAN COLLECTIVE SECURITY IN THE PERIOD FROM THE VERSAILLES PEACE CONFERENCE TO THE LOCARNO TREATY (1919-1925)}

The article examines the origins and evolution of the European system of collective security after the end of the First World War until the mid-1920s and the Locarno Treaties. Based on the analysis of international documents and literature, this study traces the development of European collective security through the League of Nations and by examining the impact of the Locarno Treaties.

Key Words: Versailles Peace Conference; collective security; League of $\mathrm{Na}$ tions; European integration; international law; Locarno Treaties. 